\title{
Kirjastojen sanataidetoiminta osallisuuden edistäjänä
}

\author{
Hanna Kleemola \\ Jyväskylän yliopisto \\ hanna.h-k.kleemola@student.jyu.fi
}

Yksi yhteiskuntamme ajankohtaisista haasteista on syrjäytyminen. Sekä taloudellisesti että sosiaalisesti merkittävän ongelman selättämiseen tarvitaan laajaa yhteistyötä. Yleiset kirjastot voivat osallistua työhön esimerkiksi edistämällä luku- ja kirjoitustaitoa ja järjestämällä osallistavaa toimintaa. Yhteisölliset sanataideaktiviteetit, kuten kirjoittajakerhot, sarjakuvakurssit, räppityöpajat ja tarinankerrontapiirit, voivat osaltaan tukea yhteiskunnan kelkasta pudonneita ja putoamassa olevia.

Vuoden 2017 alussa voimaan tulleessa kirjastolaissa korostuvat yhteisöllisyys, moniarvoisuus ja kulttuurinen moninaisuus. Laki edistää yhdenvertaisia mahdollisuuksia sivistykseen, kulttuuriin ja elinikäiseen oppimiseen sekä tukee aktiivista kansalaisuutta. Yleisten kirjastojen tehtäviin kuuluu muun muassa tukea lukutaidon kehittämistä, tarjota tiloja oppimiseen, harrastamiseen ja kansalaistoimintaan sekä edistää yhteiskunnallista ja kulttuurista vuoropuhelua. Vuorovaikutteinen, osallistava ja monipuolista lukemista edistävä sanataidetoiminta sopii mainiosti uuden kirjastolain henkeen.

Kirjastot hakevat parhaillaan uusia toimintamuotoja muun muassa digitalisaation seurauksena. Kun fyysisten kokoelmien merkitys vähenee, elämysten painoarvo kasvaa. Uudenlainen ajattelu heijastuu sekä toimintoihin että tiloihin, hyvänä esimerkkinä pian avattava Helsingin keskuskirjasto Oodi. Uuden kirjastokonseptin ja monipuolisten tilojen myötä Helsingin kaupunki pyrkii 
vahvistamaan yhteisöllisyyttä ja tarjoamaan asiakkaille mahdollisuuksia tuottaa omaehtoisesti tietoa ja kulttuuria. (Helsingin kaupunginkanslia \& Haavisto, 2016, ss. 53, 59, 61.) Uskon, että meneillä oleva murros tarjoaa luovaan ilmaisuun kannustavalle sanataidetoiminnalle mahdollisuuden vakiintua yhä keskeisemmäksi osaksi kirjastojen toimintaa (ks. Kleemola, ei pvm.).

Perinteisesti kirjastojen sanataidetoiminta on painottunut pikemminkin sanataiteen vastaanottamiseen kuin sen tuottamiseen. Kirjastonhoitajat Mervi Koski ja Marja-Leena Mäkelä ovat viime vuosikymmeninä edistäneet luovan sanataidetoiminnan juurtumista kirjastoihin. Molemmat pitävät kirjastoa ihanteellisena paikkana sanataiteen tekemiselle. (Koski, 1994, ss. 14, 22-23, 30; Mäkelä, 2005, 2015, s. 98.) Kirjastojen hankkeisiin perehtynyt kirjastonhoitaja ja kirjoittajaohjaaja Sini Kiuas on huomannut, että hankkeissa toistuu usein sanatadepajan, kirjailijavierailun ja kirjavinkkauksen yhdistelmä. Hän uskoo, että oma tekeminen auttaa osallistujia arvostamaan kirjallisuutta ja että luova toiminta on vakiinnuttanut paikkansa hankkeissa. (Kiuas, 2012, s. 59.)

Kirjastojen yhteiskunnallinen rooli on korostunut uuden kirjastolain myötä. Yhä keskeisemmäksi on noussut yhteistyö eri tahojen, kuten opetus-, kulttuuri-, nuoriso- sekä sosiaali- ja terveysalan toimijoiden, kanssa. (FINLEX, 2016.; "L 29.12.2016/1492", 2016) Yhteistyötä ja kirjastojen sosiaalista roolia on edistetty esimerkiksi Turun ja Seinäjoen ammattikorkeakoulujen ja Jyväskylän yliopiston Näkymättömät - Nuorten digitarinat -hankkeessa. Hanke tarjosi taide- ja medialähtöisiä työpajoja yhteiskunnan reunoille ajautumassa oleville nuorille aikuisille sekä koulutti ja verkostoi kirjastoammattilaisia. Räpin, sarjakuvan, luovan kirjoittamisen ja digitaalisten tarinoiden kautta kirjastojen ja nuorten välille syntyi keskusteluyhteys. (Hyttinen, 2018, ss. 100-101; Hyttinen \& Tanskanen, 2018, ss. 81-82, 90.)

Kiinnostukseni kirjastojen sanataidetoimintaan syttyi reilut kymmenen vuotta sitten, kun selvitin osana Seinäjoen ammattikorkeakoulun kirjastoja tietopalvelualan erikoistumisopintojani sanataideohjauksen tilaa EteläPohjanmaan kirjastoissa. Jyväskylän yliopiston kirjoittamisen pro gradu -tutkielmassani (Kleemola, 2015) tarkastelin Laihian, Isonkyrön ja Vähänkyrön kirjastojen koululaisille järjestämiä sanataidekerhoja, joissa toimin ohjaajana. Työskentely sanataideohjaajana, osallistujien haastatteleminen ja tutkielman laatiminen havahduttivat huomaamaan, miten tärkeää kirjastojen järjestämä matalan kynnyksen maksuton sanataidetoiminta on.

Tällä hetkellä teen Jyväskylän yliopistossa väitöstutkimusta Suomen ja muiden Pohjoismaiden kirjastojen sanataidetoiminnasta. Väitökseni sijoittuu kirjoittamisen tutkimuksen ja informaatiotutkimuksen rajapinnalle. Keskeisin tutkimuskysymykseni kuuluu: miten kirjastojen sanataidetoiminta voi ehkäistä syrjäytymistä ja lisätä hyvinvointia ja osallisuutta? Osana tutkimusta käsittelen 
kirjoittamisen ja lukemisen kytköstä. Suomessa etenkin poikien lukutaito on jatkuvasti heikentynyt. Tarkastelenkin, voiko kirjastojen sanataidetoiminta vahvistaa kirjoitus- ja lukutaitoa.

Kerään aluksi aineistoa kaikille Suomen kunnan- ja kaupunginkirjastoille suunnattavalla kyselyllä. Syvennän tarkastelua tutkimalla kirjastojen sanataideaktiviteetteja kaikissa Pohjoismaissa. Havainnoin toimintaa ja haastattelen osallistujia, ohjaajia ja kirjastojen henkilökuntaa. Tavoitteenani on paitsi tuottaa yhteiskunnallisesti merkittävää tutkimustietoa myös edistää sanataiteen soveltavaa käyttöä. Monilla Suomen kirjastoilla on intoa sanataidetoiminnan järjestämiseen, mutta tiukka taloustilanne on usein jarruna. Toimintaa toteutetaankin usein lyhytkestoisten hankeavustusten turvin. Haluan tutkimuksellani herättää päättäjät pohtimaan, kannattaako varoja suunnata yhä suunnitelmallisemmin kirjastojen sanataidetoimintaan.

\section{Lähteet}

FINLEX. (2016). HE 238/2016. Hallituksen esitys eduskunnalle laeiksi yleisistä kirjastoista ja opetus- ja kulttuuritoimen rahoituksesta annetun lain $2 \$: n$ muuttamisesta. https://finlex. $\mathrm{fi} / \mathrm{fi}$ /esitykset/he/2016/20160238

Helsingin kaupunginkanslia, \& Haavisto, T. (2016). Yhteenveto keskustakirjaston elinkeino- ja yhteiskunnallisista vaikutuksista. Teoksessa Hyötyä, tietoa, elämyksiä : kirjastojen vaikuttavuuden ulottuvuuksia (ss. 51-62). Suomen kuntaliitto. http://shop.kunnat.net/download. php?filename=uploads/kirjastot_sisalto_ebook.pdf

Hyttinen, R. (2018). Näkymättömät nuoret aikuiset. Teoksessa Kirjastot aikuisten lukemisen edistäjinä (ss. 100-101). Helsinki: Helsingin kaupunki. https://www.kirjastot.fi/sites/ default/files/content/Kirjastot/\%20aikuisten/\%20lukemisen/\%20edistajina.pdf

Hyttinen, R., \& Tanskanen, I. (2018). Kirjasto osallisuuden ja yhteistyösuhteiden solmukohtana. Informaatiotutkimus, 37(2). https://doi.org/10.23978/inf.71159

Kiuas, S. (2012). Kirjallisuuden projektit kirjastoissa. Helsinki: Avain.

Kleemola, H. (2015). Kirjaston hilijaasuures huutaa elämä : tutkimus sanataidekerhoista Pohjanmaalla (Pro gradu -tutkielma). Jyväskylän yliopisto. http://urn.fi/URN:NBN: fi:jyu201602121553

Kleemola, H. (ei pvm.). Kirjasto sanataidetoiminnan järjestäjänä. Teoksessa N. Ekström, E. Puikkonen, \& K. Suoniemi (toim.), Sanataidetta on! Työtavat, tekijät ja teoria. Turku: Kirjan talo. (Painossa).

Koski, M. (1994). Taskut täynnä tarinoita. Cultura.

L 29.12.2016/1492. (2016). https://finlex.fi/fi/laki/ajantasa/2016/20161492

Mäkelä, M.-L. (2005). Sanataidetta kirjastossa. Teoksessa M.-L. Mäkelä (toim.), Sanaista taidetta (ss. 11-24). Helsinki: BTJ Kirjastopalvelu.

Mäkelä, M.-L. (2015). Kirjavinkkarikirja (Uudistettu laitos). Avain. 